\title{
FENOMENA KESEHATAN REPRODUKSI PADA PELAJAR PUTRI DI SMA KOTA YOGYAKARTA
}

\author{
Oleh: \\ Sriadi Setyawati, Suparmini, Mawanti Widyastuti \\ Jurusan Pendidikan Geografi FIS UNY \\ sriadi_s@uny.ac.id
}

\begin{abstract}
Abstrak
Tujuan penelitian ini adalah untuk mengetahui fenomena kesehatan reproduksi remaja putri di Kota Yogyakarta. Penelitian ini adalah penelitian diskriptif kuantitatif. Metode penelitian yang digunakan adalah metode survei terhadap sampel penelitian. Populasi penelitian adalah pelajar putri di SMA Kota Yogyakarta. Jumlah populasi dalam penelitian ini sebanyak 600 pelajar putri dari tiga SMA di Kota Yogyakarta. Sampel penelitian berjumlah 90 pelajar putri, atau mengambil 15 persen dari populasi yang ada. Metode pengambilan sampel dengan 'systematic sampling'. Analisis data menggunakan analisis diskriptif dengan tabel persentase.Hasil penelitian menunjukkan fenomena kesehatan reproduksi remaja putri di Kota Yogyakarta adalah sebagai berikut: Gaya pacaran responden sebagian besar yaitu sebanyak 90 persen mengarah ke free sex. Hamil sebelum menikah sebanyak 44,50 persen, seperti dinyatakan oleh responden yang menjawab pertanyaan tentang gaya pacaran teman - temannya. Hampir separuh yaitu 46,66 persen pernah melihat VCD porno. Hanya 19,89 persen responden menyatakan bahwa temannya pernah melakukan aborsi.
\end{abstract}

Kata kunci: kesehatan reproduksi, pelajar putri

\section{Abstract}

This research aims at investigating the phenomenon of reproductive health of young women in the city of Yogyakarta. This research is a descriptive quantitative research. The research method is a survey on the research samples. The population was high school female students in Yogyakarta. The population in this research consists of 600 female students from three high schools in Yogyakarta. Moreover, the sample comprises of 90 female students or $15 \%$ from the population. The samples were taken using a systematic sampling method. The data analysis was performed using a descriptive analysis utilizing the percentage table. The results show that the phenomenon of reproductive health of young women in the city of Yogyakarta are described as follows: The courtship style of most respondents or 90 percent respondents lead to a free sex. Pregnant before marriage reaches 44.50 percent, as stated by the respondents who answered questions about the style her friends courtship. Nearly half of respondents or 46.66 percent had viewed pornographic VCDs. In addition, 19.89 percent of the respondents stated that his friends had ever performed an abortion.

Keywords: reproductive health, female students 


\section{PENDAHULUAN}

Pelajar adalah anak dewasa namun mereka belum dewasa penuh. Sehingga harus selalu mendapatkan perhatian dan nasehat - nasehat yang berguna untuk perkembangan jiwanya. Mereka masih memperlihatkan keadaan jiwa yang selalu berubah-ubah, kepribadiannya belum mantap. Bahkan sering kali melakukan penyimpangan yang keliru sehubungan dengan masa puber, pornografi, kurangnya pendidikan seks dan bimbingan dalam keluarga serta rendahnya penghayatan nilai - nilai agama.

Pelajar termasuk kelompok remaja merupakan generasi muda penerus bangsa, mempunyai karakteristik berbeda yang berhubungan dengan masa puber dan seksualitas. Maka fenomena kesehatan reproduksi remaja penting untuk diketahui. Sedangkan membicara atau menginformasikan kesehatan reproduksi kepada remaja masih dianggap tabu, maka informasi tentang kesehatan reproduksi remaja masih kurang. Padahal informasi kesehatan reproduksi bagi remaja sangat penting, maka pengetahuan kesehatan reproduksi harus diberikan dengan benar. Jika remaja putri pengetahuan kesehatan reproduksinya kurang, maka ketahanan remaja terhadap kesehatan reproduksi akan rendah atau lemah dan berdampak kurang baik. Maka saat ini sering dijumpai remaja hamil sebelum nikah bahkan fenomena tersebut ada kecenderungan jumlahnya semakin meningkat. Guna mengatasi permasalahan tersebut maka kesehatan reproduksi sebaiknya masuk dalam kurikulum. Hal ini untuk mengatasi agar pengetahuan dan pemahaman terhadap kesehatan reproduksi remaja tidak sepotong - sepotong dan pelajar mendapatkan informasi yang benar tentang kesehatan reproduksi. Sehingga pelajar dapat mengatasi hal-hal negatif yang berhubungan dengan kesehatan reproduksi remaja, dan memiliki ketahanan reproduksi yang kuat.

Sri Purwatiningsih dan Sofia Nur Yulida Furi dalam Tukiran (2010: 243), mengatakan bahwa: remaja merupakan kelompok penduduk yang perlu mendapatkan perhatian. Populasi kelompok penduduk remaja (15 - 24) tahun, menurut Sensus Penduduk 2000, sekitar 44 juta jiwa atau 20 persen dari seluruh penduduk Indonesia. Disamping populasinya yang cukup besar, persoalan yang dialami oleh remaja juga cukup kompleks. Remaja merupakan masa peralihan dari masa anak - anak menuju masa dewasa. Jika dilihat dari segi kematangan biologis dan seksual, remaja sedang menunjukkan karakteristik seks sekunder sampai mencapai kematangan seks. Sementara itu, jika dilihat dari segi perkembangan kejiwaan, mereka sedang berkembang dari sifat anak - anak menjadi dewasa.

Aden R (2010: 13 \& 38) mengatakan bahwa: remaja, seiring dengan perkembangannya mulai bereksplorasi dengan diri, nilai - nilai identitas peran dan perilakunya. Dalam masalah seksualitas sering kali remaja bingung dengan perubahan yang terjadi pada dirinya. Ketika remaja memasuki masa puber remaja mengalami perubahan fisik yang cepat, dan sudah memiliki kemampuan reproduksi. Tetapi justru banyak fenomena yang memperlihatkan sebagian remaja belum mengetahui dan memahami tentang kesehatan reproduksinya. Misal tentang masa subur, menstruasi, kehamilan yang tidak diinginkan, Infeksi Menular Seksual ( IMS ) hingga HIV/AIDS. Remaja 
adalah sumber daya manusia yang berpotensi, kesadaran mereka tentang kesehatan reproduksi penting untuk ditumbuhkan. Remaja dan kesehatan reproduksi sangat penting untuk dibahas. Pertama kita melihat resiko dan konsekuensi yang mungkin terjadi. Resiko yang dihadapi seperti Kehamilan Tidak Diinginkan (KTD), IMS termasuk HIV/AIDS, kekerasan seksual dan kegiatan seksual yang tidak diinginkan. Sedang konsekuensi yang harus ditanggung adalah dari segi medis, psikologi, sosial dan ekonomi. Perubahan fisik yang terjadi pada masa pubertas bertanggung jawab atas munculnya dorongan seks. Pemuasan dorongan seks masih dipersulit dengan banyaknya tabu sosial, sekali gus juga kekurangan pengetahuan yang benar tentang seksualitas. Namun sejak tahun 1960 an, aktivitas seksual telah meningkat diantara remaja, studi akhir menunjukkan bahwa hampir 50 persen remaja dibawah usia 15 tahun dan 75 persen di bawah usia 19 tahun telah melakukan hubungan seks.

Beberapa penelitian terkait dengan kehidupan remaja Indonesia pada pada umumnya menyimpulkan nilai - nilai hidup remaja sedang dalam proses perubahan, yaitu adanya kecenderungan untuk bertoleransi terhadap gaya hidup seksual pranikah (Suryoputro dkk dalam Tukiran, 2010: 244). Sebuah survey yang dilakukan oleh BKKBN Jawa Barat tahun 2007, misalnya, menunjukkan 40 persen remaja berusia $15-24$ tahun telah mempraktekkan seks pranikah ( Pikiran Rakyat, 10 Juli 2007, dalam Tukiran, 2010 : 244 )

Oleh karenanya pendidikan seks ( kesehatan reproduksi remaja) segera dimasukkan ke dalam kurikulum Sekolah Menengah Atas (SMA). Sehingga untuk membentuk masa depan anak - anak, pengetahuan dan konsekuensi kesehatan reproduksi dijelaskan kepada mereka. Maka perlu diketahui bagaimanakah fenomena kesehatan reproduksi remaja.

Dengan pemahaman tentang kesehatan reproduksi yang benar, remaja akan mempunyai ketahanan reproduksi yang kuat. Sehingga fenomena kesehatan reproduksi remaja seperti hamil sebelum menikah, aborsi, pacaran yang mengarah ke seks bebas, dapat berkurang. Hal inilah yang mendorong peneliti untuk memilih judul dalam tulisan ini adalah" Fenomena Kesehatan Reproduksi Remaja pada Pelajar Putri di Kota Yogyakarta"

\section{FENOMENA KESEHATAN REPRODUKSI}

Beberapa waktu yang lampau masalah remaja dengan alat reproduksinya kurang mendapat perhatian karena umur relatif muda, masih dalam status pendidikan. Sehingga seolah - olah bebas dari kemungkinan menghadapi masalah yang berkaitan dengan reproduksi. Terbukti bahwa remaja yang sedang mencari identitas diri telah sangat mudah menerima informasi dunia berkaitan dengan masalah kesehatan reproduksi. Sehingga cenderung menjurus kearah pelaksanaan hubungan seksual yang semakin bebas. Begitulah sedikit nukilan fenomena kesehatan reproduksi remaja (Ida Bagus Gde Manuaba, 1999 : 17 ). Fenomena kesehatan reproduksi pelajar putri adalah sebagai berikut: 


\section{Gaya Pacaran}

Tugas bapak ibu guru utamanya guru Bimbingan Konseling ( BK ) yaitu membantu para pelajar memecahkan masalah yang dihadapi para pelajar terutama yang mengganggu proses belajar. Misalnya masalah pacar, masalah tersebut sering mengganggu prestasi belajarnya. Pelajar SMU adalah remaja masih dalam masa akil baliq, sebagian dari mereka ada yang berpacaran. Apabila hal tersebut tidak dapat tersalur secara wajar maka dapat mengganggu studinya. Dalam keadaan demikian maka sangat diharapkan bimbingan dari berbagai pihak utamanya adalah guru Bimbingan dan Penyuluhan. Hasil penelitian gaya pacaran pelajar putri di kota Yogyakarta adalah sebagai berikut:

Hasil penelitian menunjukkan bahwa sebagian besar 48 responden atau 53,33 persen telah mempunyai pacar. Ternyata gaya pacaran siswa SMU saat ini telah mengarah ke seks bebas atau "free sex", seperti dinyatakan oleh sebagian besar 81 responden atau 90 persen. Berarti siswa yang pacarannya tidak mengarah ke "freesex" hanya 9 responden atau 10 persen saja. Begitulah pernyataan responden ketika menjawab pertanyaan tentang gaya pacaran teman - temannya. Pada umumnya responden menentang jika teman-temannya berpacaran sampai mengarah ke "free sex", hal tersebut dinyatakan oleh 82 responden atau 91,11 persen yang menyatakan sangat tidak setuju dan 7 responden atau 7,77 persen menyatakan tidak setuju, tetapi terdapat 1 responden atau 1,11 persen yang setuju dengan gaya pacaran "free sex". Meskipun jumlahnya sangat kecil hal ini harus diperhatikan karena masalah "free sex " masalah " gunung es," yang kelihatan sedikit tetapi masalah "free sex " yang tidak kelihatan sebenarnya sangat besar. Oleh karena itu orang tua, guru dan warga masyarakat harus dapat menjadi teladan bagi anakanak dan lingkungannya. Agar fenomena reproduksi yang tidak sehat tidak melanda remaja dan remaja memiliki ketahanan terhadap kesehatan reproduksi. Maka pendidikan sex hendaknya masuk pada kurikulum sekolah bahkan segera diberikan sejak usia dini.

Seperti pernyataan lip Wijayanto dan Sri rejeki (2004:2) adalah sebagai berikut :

Pendidikan seks bebas yang menjalar di kalangan remaja menjadi masalah serius. Paling tidak berubahnya orientasi seks para remaja kepada pemahaman yang keliru, seperti pemahaman hasrat seksual tanpa ikatan apapun, berdalih suka sama suka. Untuk itulah ia mengusulkan pendidikan seks yang benar harus diberikan sejak usia dini ataupun remaja. Dunia pendidikan harusnya berbuat sesuatu dengan munculnya seks bebas tersebut. Gambaran situasi saat ini yang tidak mungkin diabaikan oleh masyarakat apalagi pengambil kebijakan untuk disampaikan kepada remaja dan juga masyarakat pada umumnya. Kalau remaja melakukan hubungan seks kurang dari umur 20 tahun, maka ia sudah melakukan investasi pertama kanker mulut rahim. Pertanyaannya, akankah kita diam tanpa memberikan bekal pada remaja tentang pengetahuan kesehatan reproduksi secara sehat dan benar kepada mereka.

Sri Purwatiningsih dan Sofia Nur Yulida Furi dalam Tukiran (2010: 252 \& 254), mengatakan : gaya remaja dalam berpacaran pun juga terjadi perubahan. Bila remaja Zaman dulu dalam menunjukkan rasa kasih sayang mereka terhadap pacarnya hanya 
sebatas ngobrol, curhat saja, tampaknya hal itu tidak berlaku lagi saat ini. Para remaja lebih suka menunjukkan rasa kasih sayang mereka terhadap pacarnya tidak hanya sebatas mengobrol atau curhat saja. Model remaja berpacaran saat ini sudah mengalami perubahan, bahkan cenderung mengarah pada pergaulan bebas. Rasa ingin tahu yang membawa remaja pada tindakan coba - coba rupanya juga menjadi salah satu alasan yang mendasari remaja melakukan hubungan seksual. Data Survei Demografi dan Kesehatan Indonesia (SDKI) 2007, menunjukkan bahwa sebagian besar alasan remaja untuk melakukan hubungan seksual adalah rasa keingintahuan atau penasaran, yaitu sebanyak 45,60 persen remaja menggunakan alasan tersebut, menjawab pertanyaan mengapa mereka melakukan hubungan seksual untuk pertama kalinya. Sementara itu ketidaktahuan remaja terhadap dampak jika mereka melakukan hubungan seksual mengakibatkan remaja tidak memikirkan akibat perbuatan mereka. Sehingga sering melakukannya begitu saja tanpa memikirkan akibatnya. Ketidaktahuan remaja ini ditunjukkan dari cukup besarnya remaja yang mengatakan bahwa hubungan seksual untuk pertama kalinya terjadi begitu saja, yaltu sebanyak 27,70 persen.

Pelayanan kesehatan reproduksi untuk remaja juga merupakan hal yang penting, sehingga terdapat informasi - informasi yang berhubungan dengan permasalahan kesehatan reproduksi remaja sampai kepada kelompok remaja. Misal masalah hamil sebelum menikah, seks bebas, narkoba, HIV, AIDS dll. Hal ini merupakan masalah yang penting untuk diketahui oleh remaja, agar mereka mempunyai ketahanan terhadap kesehatan reproduksi. Sehingga masalah kesehatan reproduksi remaja yang menyimpang dapat ditekan.

\section{Hamil Sebelum Nikah}

Penelitian menunjukkan bahwa kejadian semakin bebasnya hubungan seksual, seolah-olah mencoreng muka pendidik, orang tua dan masyarakat sehingga menimbulkan kesadaran yang agak terlambat. Penelitian di Jakarta, Yogyakarta dan Denpasar menunjukkan bukti bahwa dikalangan remaja telah terjadi revolusi dalam hubungan seksual menuju kearah liberalisasi tanpa batas. Kebanggaan terhadap kemampuan untuk mempertahankannya sampai pada jenjang pelaminan telah sirna, oleh karena kedua belah pihak saling menerima kedudukan baru dalam seni pergaulan hidupnya (Ida Bagus Gde Manuaba, 1999: 17). Keadaan hamil sebelum menikah adalah sebagai berikut:

Keadaan hamil sebelum menikah teman - teman responden, hasil penelitian menunjukkan bahwa 50 responden atau 55,55 persen menjawab teman -temannya hamil sebelum menikah dan 40 responden atau 44,45 persen menjawab teman - temannya tidak ada yang hanmil sebelum menikah. Dari 50 responden tersebut terdapat 17 responden atau 34 persen menyatakan hanya ada 1 orang temannya yang hamil sebelum menikah, 18 responden atau 36 persen menyatakan 2 orang, 11 responden atau 22 persen menyatakan 3 orang dan 4 responden atau 8 persen menyatakan 4 orang temannya yang hamil sebelum menikah. Kasus - kasus tersebut menyebabkan pelajar harus kawin pada usia muda, "free sex " pada pelajar akan mengakibatkan kehamilan 
sebelum menikah (kehamilan yang tidak diinginkan dan penyakit menular lainnya). Dua masalah tersebut juga akan menjerumuskan pelajar pada permasalahan yang sulit dipecahkan dan mempunyai dampak yang merugikan bagi masa depan pelajar.

Karena hamil sebelum menikah maka sudah dapat ditebak bahwa kehamilan tersebut tidak diinginkan, jadi merupakan suatu kehamilan yang tidak disambut dengan menggembirakan. Sehingga muncul pikiran usaha untuk menghilangkannya atau menggugurkan. Menggugurkan atau aborsi merupakan jalan pintas yang sering dilakukan sebelum janin dalam kandungan semakin tumbuh besar, sebelum berumur kira - kira mencapai 20 Minggu. Aden R (2006 : 111) mengatakaan: ada banyak alasan mengapa melakukan aborsi. Tak hanya alasan karena kehamilan dilakukan karena seks di luar nikah. Pasangan yang telah menikahpun banyak yang melakukannya, dan memiliki berbagai alasan. Sayangnya tidak semua memahami resiko yang akan dialami jika mereka melakukan aborsi. Tak hanya kesehatan dan keselamatan jiwa yang terancam, secar psikis pun perempuan akan merasakan dampak yang sangat hebat. Pasca aborsi perempuan akan mengalami Post Abortion Syndrome (Sindrom Paska Aborsi), dengan perasaan bersalah yang tidak hilang selam bertahun - tahun dalam hidupnya.

Ida Bagus Gde Manuaba (1999: 20), mengatakan bahwa : secara sosial hubungan seks baru diperbolehkan bila telah terikat dalam perkawinan. Di tengah masyarakat Indonesia yang berdasar Pancasila, belum dapat diterima kehamilan tanpa satus perkawinan yang resmi, atau hidup bersama tanpa pernikahan. Menghadapi gerakan keluarga berencana dianjurkan untuk menikah pada usia yang relatif dewasa (20 - 25 tahun). Sehingga diperlukan waktu panjang mencapai umur tersebut. Menghadapi penundaan perkawinan ini para remaja memerlukan penyaluran diri sehingga terhindar dari berbagai aspek hubungan seks yang dilakukan secara sembrono. Hubungan seks yang bebas sudah tentu akan menimbulkan akibat yang tidak diinginkan yaitu kehamilan yang belum dikehendaki dan penyakit hubungan seks. Dalam situasi masa panca roba dan menunggu sampai usia kawin inilah peranan orang tua sangat penting, mengarahkan remaja menuju tingkah laku yang positif dan terutama dalam pendidikan. Sehingga dapat mencapai sasaran belajar yang dikehendaki. Disamping itu tingkah laku orang tua pun tidak kalah pentingnya menjadi contoh dan panutan remaja dalam bertingkah laku.

\section{VCD Porno}

Seks bebas yang menjerumuskan pelajar pada pemahaman seks yang keliru disebabkan oleh banyak faktor. Salah satu faktor luar yang berpengaruh adalah VCD porno. Hasil penelitian menunjukkan akses VCD porno para pelajar SMU berasal dari rental, teman dan lain - lain adalah sebagai berikut : hampir separo yaitu 42 responden atau 46,66 persen pernah melihat VCD porno dan 48 responden atau 53,34 persen belum pernah melihat VCD porno. VCD porno tersebut berasal dari teman sebanyak 32 responden atau 76,19 persen, rental 10 responden atau 23,81 persen. Ternyata HP juga berfungsi sebagai informasi pornografi yang dikirimkan ke teman lainnya. Hal tersebut akan membawa pengaruh negatif terhadap perilaku seseorang. 
Sri Lestari (2006: 11) mengatakan bahwa : dalam masyarakat kita masih banyak orang tua yang merasa tabu untuk mengajarkan masalah kesehatan reproduksi. Akhirnya anak - anak memcari tahu melalui teknologi canggih yang mudah seperti TV, VCD, internet dan mereka tidak menyadari bahwa informasi itu justru dapat menjerumuskan mereka.

Sri Purwatiningsih dan Sofia Nur Yulida Furi dalam Tukiran (2010: 252) mengatakan : perkembangan teknologi dan semakin mudahnya remaja memperoleh informasi dari berbagai media membuat pergaulan mereka juga semakin berbeda. Jika dulu mempunyai pacar itu dianggap tabu, sekarang kondisinya justru terbalik, remaja yang tidak mempunyai pacar dianggap ketinggalan zaman dan kurang pergaulan. Berdasarkan data SDKI 2007, sebanyak 74 persen remaja pernah mempunyai pacar dan usia pertama kali mempunyai pacar terbanyak pada usia 15 - 19 tahun mencapai sekitar dua pertiganya. Remaja perempuan mempunyai pacar lebih awal dari pada laki - laki.

Fenomena kesehatan reproduksi yang menyimpang itu dapat terjadi karena sejumlah faktor. Selain faktor masa puber, dorongan nilai - nilai dan keyakinan pribadi juga sangat berpengaruh. Maraknya pornografi, kurangnya pendidikdn seks, kurangnya berbagai faktor lain sangat menentukan bagaimana seseorang memiliki perilaku seksualnya (Anonim, $2004: 7$ )

\section{Aborsi Disengaja}

Aborsi disengaja dalam penelitian ini adalah aborsi ilegal, sebabnya dapat berupa rasa malu dan untuk menghilangkan jejak. Akibat yang timbul selain gagalnya kelahiran juga dapat mengancam keselamatan calon ibu maupun fungsi reproduksi selanjutnya. Oleh karena sifatnya yang ilegal, maka erat kaitannya dengan penyimpangan seksual (Soemantri Wardoyo, 1995: 5). Hasil penelitian menunjukkan aborsi disengaja adalah sebagai berikut : sebagian besar 73 responden atau 80,11 persen menyatakan bahwa temannya tidak ada yang melakukan aborsi. Hanya 17 responden atau 19,89 persen menyatakan bahwa temannya pernah melakukan aborsi. Dari 17 responden tersebut terdapat 12 responden atau 70,59 persen yang menyatakan hanya 1 orang temannya yang melakukan aborsi, 2 orang responden atau 11,76 persen menyatakan 3 orang dan 3 responden atau 17,65 persen menyatakan hanya 1 orang temannya yang melakukan aborsi.

Yayah khisbiyah dkk (1997: 49 - 50) mengatakan: kehamilan pranikah yang berakhir denagn aborsi dapat diinterpretasikan sebagai solusi untuk menghilangkan ketakutan atau kekuatiran sosial ekonomi, dan untuk mengembalikan individu pelaku maupun keluarganya kepada definisi tentang struktur masyarakat dan struktur keluarga yang disepakati bersama. Pada kasus - kasus remaja yang memilih aborsi, pertimbangan rasa aman dari kemungkinan terputusnya pendidikan dan gagalnya cita-cita, kekecewaan dan kemarahan orang tua, tercemarnya nama baik keluarga, pelecehan sosial, ketidakjelasan status anak, dan kecemasan akan kesanggupan memenuhi kebutuhan ekonomi, atau alasan-alasan eksternal lain, mengalahkan pertimbangan nilai hidup seorang calon manusia. Sering kali ini bukan keputusan yang mudah dan menyiksa hati 
nurani. Dengan aborsi, para remaja ini telah mampu menyelamatkan diri mereka dari perasaan malu, kalau-kalau masyarakat mengetahui perilaku seks dan kehamilan pranikah mereka. Akan tetapi, sebagai gantinya, banyak yang merasa semakin berdosa, karena hati nurani mereka mengatakan bahwa aborsi adalah salah dalam konstruk nilai - nilai transendental. Hampir semua responden yang melakukan aborsi mengalami sindroma pasca aborsi, penyesalan dan perasaan berdosa, self - esteem yang rendah, stres, sampai ke mimpi buruk, insomnia, bahkan depresi.

Endang Purwoastuti (2003: 58) mengatakan bahwa : saat ini sering diberitakan di dalam media masa banyak dikalangan remaja yang telah melakukan penyimpangan perilaku seks bebas yang saat ini telah merebak dikalangan remaja khususnya di kota Yogyakarta. Maka keluarga mempunyai peranan yang sangat penting dalam pembentukan pribadi anak. Keluarga mempunyai tugas untuk membimbing, mengatur serta mendidik anak sebelum anak terjun kedalam proses pergaulan dunia luar. Seandainya peranan tersebut dijalankan dengan baik oleh setiap keluarga maka diharapkan anak tidak akan mengalami kerusakan mental dan pribadi akibat dari pengaruh dunia luar. Karena anak telah mempunyai dasar pribadi yang positif dan kuat.

\section{KESIMPULAN}

Berdasarkan hasil penelitian dan pembahasan dapat ditarik beberapa kesimpulan sebagai berikut:

1. Responden menyatakan bahwa lebih dari separuh yaitu 53,33 persen temannya telah mempunyai pacar

2. Gaya pacaran siswa smu sebagian besar yaitu 90 persen mengarah ke free sex

3. Karena free sex menyebabkan pelajar hamil sebelum menikah, menikah pada usia muda, kehamilan yang tidak diinginkan dan penyakit menular

4. Hampir separo yaitu 46,66 persen pernah melihat VCD porno, dan sebagian besar 79,19 persen VCD porno tersebut berasal dari teman

5. Sebagian besar yaitu 80,11 persen menyatakan bahwa temannya tidak ada yang melakukan aborsi. Ini berarti bahwa sebesar 19,89 persen temannya ada yang melakukan aborsi

\section{SARAN}

Saran-saran terkait hasil penelitian ini adalah sebagai berikut :

1. Perlunya pengawasan dan bimbingan bagi pelajar dari orang tua dan sekolah serta masyarakat

2. Mengoptimalkan keberadaan Pusat Informasi dan Konseling Remaja (PIK-R) guna meningkatkan pengetahuan dan konseling tentang kesehatan reproduksi

3. Mengadakan kerja sama antar lembaga terkait untuk melaksanakan penyuluhan guna ketahanan kesehatan reproduksi remaja dan bahaya perilaku seksual yang menyimpang

Dengan adanya kesimpulan seperti tersebut diatas maka disarankan kepada semua pihak, orang tua, guru dan masyarakat untuk lebih memperhatikan masalah yang dihadapi oleh 
pelajar terutama yang berhubungan dengan kesehatan reproduksi, adalah sebagai berikut:

1. Pendidikan seks yang benar segera diberikan kepada pelajar, agar mereka mengerti baik buruknya kesehatan reproduksi dan tidak terjerumus pada hal - hal yang tidak diinginkan ( seks bebas).

2. Bagi orang tua, guru dan masyarakat harus berupaya untuk meningkatkan kemampuan dalam memberikan pendidikan khususnya tentang kesehatan repruduksi dan nilai - nilai agama, serta kebudayaan kepada pelajar.

3. Kepada semua pihak dapat memberikan teladan kepada pelajar.

4. Meningkatkan aktivitas pelajar sehingga mempunyai program - program yang produktif.

\section{UCAPAN TERIMA KASIH}

Penelitian ini dibiayai dengan dana DIPA FIS UNY melalui hibah penelitian kelompok Fakultas IImu Sosial Universitas Negeri Yogyakarta. Penulis mengucapkan terima kasih atas pembiayaan yang diberikan sehingga penelitian ini dapat dilaksanakan. Penulis juga mengucapkan terima kasih kepada berbagai pihak yang telah membantu dalam pelaksanaan penelitian ini.

\section{DAFTAR PUSTAKA}

Aden R. 2006. Ketika Remaja dan Pebertas Tiba. Yogyakarta : Hanggar Kreator Anonim. 2004. Di Yogya Kasus Seks Pranikah Meningkat. Yogyakarta : Minggu Pagi.

Endang Purwoastuti. 2003. Penyimpangan Perilaku Seksual Di Kalangan Remaja. Yogyakarta : WUNI UNY.

Ida Bagus Gde Manuaba. 1999. Memahami Kesehatan Reproduksi Wanita. Jakarta : Arcan.

lip Wijayanto \& Sri Rejeki. 2004. Seks Bebas Potret Nyata Rusaknya Pendidikan. Yogyakarta : Kedaulatan Rakyat.

Yayah Khisbiyah. 1997. Kehamilan Tak Dikehendaki di Kalangan Remaja. Yogyakarta : Pusat Penelitian Kependudukan UGM

Tukiran dkk. 2010. Keluarga Berencana dan Kesehatan Reproduksi. Yogyakarta : Pusat Studi Kependudukan dan Kebijakan UGM

Soemantri Wardoyo. 1995. Pelecehan Seksual Dan Aborsi. Yogyakarta : FPIPS IKIP Yogyakarta.

Sri Lestari. 2006. Pentingnya Pendidikan Seks Di Sekolah.Yogyakarta : Kedaulatan Rakyat. 